\title{
Inorganic and organic trace mineral supplementation in weanling pig diets
}

\author{
MARIA C. THOMAZ ${ }^{1}$, PEDRO H. WATANABE ${ }^{2}$, LEONARDO A.F. PASCOAL ${ }^{3}$, \\ MURILO M. ASSIS ${ }^{1}$, URBANO S. RUIZ ${ }^{4}$, ALESSANDRO B. AMORIM ${ }^{5}$, SUSANA Z. SILVA ${ }^{1}$, \\ VIVIAN V. ALMEIDA ${ }^{1}$, GABRIEL M.P. MELO ${ }^{6}$ and RIZAL A. ROBLES-HUAYNATE ${ }^{1}$

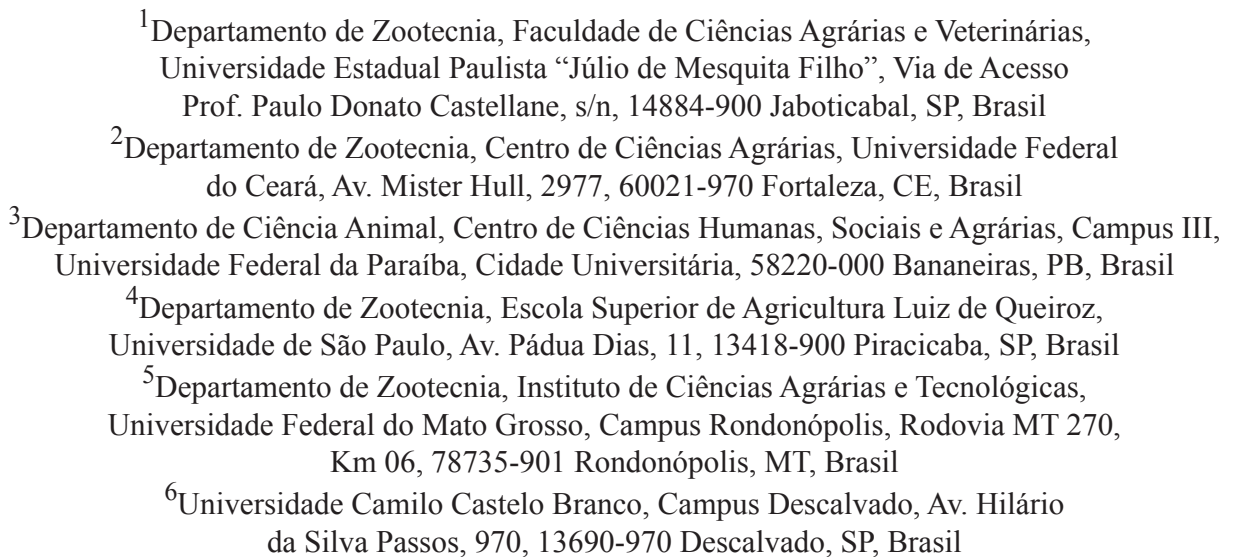

Manuscript received on April 8, 2014; accepted for publication on September 12, 2014

\begin{abstract}
A study was conducted to evaluate the effects of dietary inorganic and organic trace minerals in two levels of supplementation regarding performance, diarrhea occurrence, hematological parameters, fecal mineral excretion and mineral retention in metacarpals and liver of weanling pigs. Seventy piglets weaned at 21 days of age with an average initial body weight of $6.70 \pm 0.38 \mathrm{~kg}$ were allotted in five treatments: control diet (no added trace mineral premix); 50\% ITMP (control diet with inorganic trace mineral premix supplying only $50 \%$ of trace mineral requirements); 50\% OTMP (control diet with organic trace mineral premix supplying only $50 \%$ of trace mineral requirements); $100 \%$ ITMP (control diet with inorganic trace mineral premix supplying 100\% of trace mineral requirements); and 100\% OTMP (control diet with organic trace mineral premix supplying $100 \%$ of trace mineral requirements). Feed intake and daily weight gain were not affected by treatments, however, piglets supplemented by trace minerals presented better gain:feed ratio. No differences were observed at calcium, phosphorus, potassium, magnesium, sodium and sulfur excreted in feces per kilogram of feed intake. Treatments did not affect calcium, phosphorus, magnesium, sulfur and iron content in metacarpals. Trace mineral supplementation, regardless of level and source, improved the performance of piglets.
\end{abstract}

Key words: nursery phase, performance, weaning, piglet.

Correspondence to: Pedro H. Watanabe

E-mail: pedrowatanabe@ufc.br 


\section{INTRODUCTION}

In animal nutrition, trace minerals are used in premixes as inorganic oxides, sulphates, and carbonates, and thus act as catalysts in enzymatic and hormonal processes, influencing maintenance, growth, and bone development (Underwood and Suttle 1999). Nevertheless, the deficiency of these minerals is manifested in many metabolic processes, resulting in lower performance and immune response, being primarily evidenced in animals more susceptible to nutritional effects, such as piglets at nursery phase. Mineral imbalance or mineral deficiency may be caused by the amount of trace minerals below the animal requirement or the presence of antagonistic compounds in diet, which directly affects the absorption of several minerals. Thus, trace minerals are often supplemented in livestock diets at concentrations well above those required by the animals, aiming not to limit the productive performance. Consequently, providing minerals in excess, which are not absorbed by the animal, results in higher levels of these in manure, being potential contaminants of soil and water (Case and Carlson 2002).

With regards to the environmental impact caused by pigs manure, alternatives are evaluated aiming to reduce the waste of nutrients, including trace minerals. One of them is using trace minerals in organic form based on the higher bioavailability of them, which would allow the reduction of mineral supplementation in diets (Baker 1991). By definition, organic minerals are those which have complexed to organic molecules comprising amino acids, carbohydrates, and proteins, as well as other possible linkable components (Mellor 1964). The increased bioavailability of organic minerals might be due to the action of some components in absorption process. Another form of organic minerals effect is based on the formation of stable complexes, which decrease the possibility of forming precipitated salts with compounds, such as phytic acid or insoluble fiber. Thereby, organic trace minerals have become more available due to its greater solubility, and absorption is facilitated by the organic binder components (Kirchgessner and Grassmann 1970).

Newly weaned piglets are very susceptible to enteric disorders mostly during the first week after weaning, and thus sources of minerals that have a higher availability are beneficial not only from a nutritional standpoint but also in relation to the immune effect of certain minerals such as zinc and copper. It has been demonstrated that inorganic and organic trace mineral supplementation did not affect growth performance of pigs (Mahan et al. 1999, Revy et al. 2002). In addition, nursery pig diets are often formulated with mineral levels above those that would be required by animals and thus possible effects of organic supplementation may not be evident.

This study was aimed to determine the effects of dietary inorganic and organic trace minerals $(\mathrm{Cu}, \mathrm{Fe}, \mathrm{Mn}, \mathrm{Se}$, and $\mathrm{Zn})$ in different levels of supplementation with regards to performance, diarrhea occurrence, hematological parameters, fecal mineral excretion, and mineral retention in metacarpals and liver of weanling pigs.

\section{MATERIALS AND METHODS}

All experimental procedures were conducted in accordance with the protocol approved by the Animal Care and Use Committee of Faculdade de Ciências Agrárias e Veterinárias, Universidade Estadual Paulista "Júlio de Mesquita Filho".

\section{ANIMAL, HOUSING, AND EXPERIMENTAL DESIGN}

A total of 70 commercial strain mixed-sex (35 barrows and 35 females) pigs with an average initial body weight (BW) of $6.70 \pm 0.38 \mathrm{~kg}$ were obtained after weaning at 21 days of age for use in the current study. The pigs were housed in floor pens (length $=3.0 \mathrm{~m}$; width $=3.0 \mathrm{~m}$ ) equipped with a nipple drinker, two-space feeder, and concrete flooring. The pigs were weighed and blocked by 
initial BW and allotted to five experimental diets according to a randomized complete block design. There were seven pen replicates of two pigs (one barrow and one female) per pen for each treatment.

\section{EXPERIMENTAL DIETS}

A three-phase feeding program was used with cornsoybean meal-based diets: pre-starter I (from 0 to 9 days), pre-starter II (from 10 to 29 days), and starter (from 30 to 42 days). The treatments (as-fed basis) were: control diet (no added trace mineral premix); 50\% ITMP (control diet with inorganic trace mineral premix supplying only $50 \%$ of the animal requirements); 50\% OTMP (control diet with organic trace mineral premix supplying only $50 \%$ of trace mineral requirements); $100 \%$ ITMP (control diet with inorganic trace mineral premix supplying $100 \%$ of trace mineral requirements); and 100\% OTMP (control diet with organic trace mineral premix supplying $100 \%$ of the animal requirements) (Table I).

All diets were formulated to meet or exceed Rostagno et al. (2005) requirements for all nutrients except $\mathrm{Cu}, \mathrm{Fe}, \mathrm{Mn}, \mathrm{Se}$, and $\mathrm{Zn}$. Metal proteinates

TABLE I

Composition of the experimental diets, as-fed basis (\%).

\begin{tabular}{|c|c|c|c|}
\hline \multirow{2}{*}{ Ingredient } & \multicolumn{3}{|c|}{ Experimental period (days) } \\
\hline & $0-9$ & $10-29$ & $30-42$ \\
\hline Corn & 52.76 & 57.00 & 67.57 \\
\hline Soybean meal (45\%) & 31.84 & 31.70 & 28.43 \\
\hline Milk product ${ }^{\mathrm{a}}$ & 7.00 & 4.82 & - \\
\hline Sugar & 1.00 & 0.75 & - \\
\hline Soybean oil & 1.42 & 1.42 & 0.97 \\
\hline Dicalcium phosphate & 2.36 & 1.79 & 1.60 \\
\hline Limestone & 0.54 & 0.73 & 0.63 \\
\hline Salt & 0.60 & 0.49 & 0.46 \\
\hline L- lysine.HCL & 0.76 & 0.46 & 0.20 \\
\hline L- threonine & 0.28 & 0.16 & 0.02 \\
\hline DL-methionine & 0.14 & 0.09 & - \\
\hline L- tryptophan & 0.04 & 0.01 & - \\
\hline Vitamin premix ${ }^{\mathrm{b}}, \%$ & 0.10 & 0.10 & 0.10 \\
\hline Organic/inorganic trace mineral supplementation ${ }^{\mathrm{c}}$ & - & - & - \\
\hline Antioxidant (BHT), \% & 0.02 & 0.02 & 0.02 \\
\hline Colistin, \% & 0.03 & 0.03 & 0.03 \\
\hline Inert (kaolin), \% & 1.19 & 0.40 & 0.37 \\
\hline Total & 100.00 & 100.00 & 100.00 \\
\hline \multicolumn{4}{|l|}{ Calculated values } \\
\hline Crude protein, $\%$ & 21.00 & 21.00 & 18.13 \\
\hline Calcium, \% & 0.89 & 0.80 & 0.72 \\
\hline Available phosphorus, $\%$ & 0.56 & 0.45 & 0.40 \\
\hline Metabolizable energy (kcal/kg) & 3,225 & 3,225 & 3,230 \\
\hline Digestible lysine (\%) & 1.52 & 1.33 & 0.99 \\
\hline Digestible methionine (\%) & 0.43 & 0.37 & 0.25 \\
\hline Digestible tryptophan (\%) & 0.26 & 0.23 & 0.19 \\
\hline Digestible threonine (\%) & 0.96 & 0.84 & 0.62 \\
\hline
\end{tabular}

${ }^{a}$ Nuklospray $40 \%$ of lactose. ${ }^{b}$ Provided per kilogram of diet. ${ }^{\mathrm{c}}$ Supplementation of 0.125 (50\% IM or $50 \%$ $\mathrm{OM})$ and $0.250 \mathrm{~kg}(100 \% \mathrm{IM}$ or $100 \% \mathrm{OM})$, depending on treatment. 
of $\mathrm{Cu}, \mathrm{Fe}, \mathrm{Mn}, \mathrm{Se}$, and $\mathrm{Zn}$ and their corresponding inorganic salts were used in the preparation of organic and inorganic trace mineral premixes, respectively (Table II). Both trace mineral premixes contained I and Co from inorganic source. Crystalline lysine, threonine, methionine and tryptophan were added to obtain equal amounts of digestible amino acids in all experimental diets.

TABLE II

Inorganic and organic trace mineral premixes.

\begin{tabular}{lccc}
\hline Inorganic trace mineral premix & Purity (\%) & $\begin{array}{c}\text { Amount (mg/kg of } \\
\text { premix) }\end{array}$ & Amount (g/ton of diet) \\
\hline Copper sulfate & 25.00 & 12.00 & 48.00 \\
Iron sulfate & 30.00 & 80.00 & 266.67 \\
Manganese sulfate & 31.00 & 40.00 & 129.03 \\
Zinc sulfate & 35.00 & 100.00 & 285.71 \\
Sodium selenite & 45.00 & 0.36 & 0.80 \\
Calcium iodate $*$ & 62.00 & 1.00 & 1.61 \\
Cobalt sulfate * & 20.00 & 0.20 & 1.00 \\
\hline Subtotal & & & 732.83 \\
Inert ** & & & 1767.17 \\
Total & Purity (\%) & premix) & $2500.00^{1}$ \\
\hline Organic trace mineral premix & 10.00 & 12.00 & Amount (g/ton of diet) \\
\hline Copper proteinate & 15.00 & 80.00 & 120.00 \\
Iron proteinate & 10.00 & 40.00 & 533.33 \\
Manganese proteinate & 15.00 & 100.00 & 40.00 \\
Zinc proteinate & 0.10 & 0.36 & 666.67 \\
Selenium proteinate & 62.00 & 1.00 & 360.00 \\
Calcium iodate $*$ & 0.20 & 1.61 \\
Cobalt sulfate * & 20.00 & & 1.00 \\
\hline Subtotal & & & 2082.61 \\
Inert** & & & 417.39 \\
Total & & & $2500.00^{1}$ \\
\hline
\end{tabular}

${ }^{1}$ Trace mineral supplementation at $0.25 \%$ or $2.5 \mathrm{~kg}$ / ton of diet to meet $100 \%$ of mineral recommendation;

* In treatments where there were trace mineral supplementation, and iodine and cobalt were added at level of 1.0 and $0.2 \mathrm{mg} / \mathrm{kg}$ of diet, respectively, both inorganic source. ** qsp - kaolin.

\section{PERFormanCE AND DiARRHEA OCCURRENCE}

Body weight and feed disappearance were recorded on day 9,29 , and 42 to calculate average daily gain $(\mathrm{ADG})$, average daily feed intake (ADFI), and gain to feed ratio $(\mathrm{G}: \mathrm{F})$

During the first 21 days of the trial period, fecal scores of piglets were evaluated to verify the influence of treatment on diarrhea occurrence, adapted from Vassalo et al. (1997). Macroscopic appearance of feces were observed by visual analysis according to the following scores: 1 normal feces, 2 - soft feces and 3 - watery feces. Scores 1 and 2 were considered non-diarrheal and score 3 as diarrheal feces.

\section{CHEMICAL ANALYSIS}

On day 42 , blood samples $(5 \mathrm{~mL})$ were collected from all pigs via sinus orbital puncture into sterilized tubes without anticoagulant. Samples were then immediately centrifuged at $3000 \mathrm{rpm}$ x $g$ for $20 \mathrm{~min}$ at $4{ }^{\circ} \mathrm{C}$ to recover serum. Hematological parameters (hemoglobin, hematocrit, leukocytes, eosinophils, rod neutrophil, segmented neutrophils, lymphocytes, and monocytes) were determined using the ACT-CAP coulter kit.

Fecal samples were collected for the last 13 days of the experimental period to evaluate mineral excretion. Samples were dried and grounded at ball mill. Samples were processed by nitric perchloric 
digestion and content of $\mathrm{P}, \mathrm{Ca}, \mathrm{K}, \mathrm{Mg}, \mathrm{Na}, \mathrm{S}, \mathrm{Cu}, \mathrm{Fe}$, $\mathrm{Mn}$, and $\mathrm{Zn}$ were determined in an atomic absorption spectrophotometer (Bataglia et al. 1983). Mineral excretion was calculated by relating the amount excreted with the daily intake of each mineral.

At the end of the 42-day study period, one pigs per pen, totaling 35 animals, were stunned electrically and slaughtered to harvest the liver and the third and fourth metacarpals for mineral concentration ( $\mathrm{Ca}, \mathrm{P}, \mathrm{Mg}, \mathrm{S}, \mathrm{Cu}, \mathrm{Fe}, \mathrm{Mn}$, and $\mathrm{Zn}$ ) analysis, using the same methodology as applied to the feces. The liver was analyzed by wet digestion (Delves 1982) and the metacarpals were processed and analyzed according to the method described by Veloso et al. (2000).

\section{STATISTICAL ANALYSIS}

Data were subjected to analysis of variance using GLM procedure of Statistical Analysis System software. Significant result for analysis of variance of means $(P<0.05)$ was followed by orthogonal contrasts, as $\mathrm{C} 1$ - control diet versus other treatments; $\mathrm{C} 2-50 \%$ of the animal requirements of trace mineral versus $100 \%$ of the animal requirements of trace mineral; C3 - 50\% ITMP versus 50\% OTMP and C4 - 100\% ITMP versus 100\% OTMP. For hematological parameters of eosinophils, rod neutrophil and monocytes, data were transformed in $(\mathrm{Y}+1)^{1 / 2}$ for normal distribution. Data not statistically significant were not discussed in the present work.

\section{RESULTS AND DISCUSSION}

\section{PERformance AND DiARRHEA OCCURRENCE}

In the first period (from 0 to 9 days), it was observed that the animals that received trace mineral supplementation had a lower ADFI when compared with CN (Table III).

The animals that received the organic form of trace mineral had lower ADFI, compared with those which received inorganic supplementation meeting 50 or $100 \%$ of trace mineral requirement. Although no effect of treatments in ADG, G:F was better when trace mineral supplementation met $100 \%$ of the required. For the second period (21 to 50 days of age), the piglets fed trace mineral supplementation

\section{TABLE III}

Effects of inorganic and organic trace mineral supplementation on body weight (BW), average daily gain (ADG), average daily feed intake (ADFI), and gain: feed ratio (GF) of weanling pigs.

\begin{tabular}{|c|c|c|c|c|c|c|c|c|c|c|}
\hline \multirow[b]{2}{*}{ Item } & \multicolumn{5}{|c|}{ Treatment } & \multirow[b]{2}{*}{ SEM } & \multicolumn{4}{|c|}{ P-value } \\
\hline & Control & $\begin{array}{l}50 \% \\
\text { ITMP }\end{array}$ & $\begin{array}{c}50 \% \\
\text { OTMP } \\
\end{array}$ & $\begin{array}{l}100 \% \\
\text { ITMP }\end{array}$ & $\begin{array}{l}100 \% \\
\text { OTMP } \\
\end{array}$ & & $\mathrm{C} 1$ & $\mathrm{C2}$ & $\mathrm{C3}$ & $\mathrm{C} 4$ \\
\hline \multicolumn{11}{|c|}{$0-9$ days } \\
\hline ADG, $\mathrm{g}$ & 122 & 91 & 72 & 99 & 81 & 17.52 & NS & NS & NS & NS \\
\hline ADFI, g & 239 & 225 & 158 & 204 & 141 & 24.25 & $*$ & NS & $*$ & $*$ \\
\hline GF & 0.51 & 0.41 & 0.45 & 0.48 & 0.57 & 0.07 & NS & $*$ & NS & NS \\
\hline \multicolumn{11}{|c|}{$10-29$ days } \\
\hline ADG, $\mathrm{g}$ & 164 & 217 & 254 & 235 & 207 & 13.75 & $*$ & NS & NS & NS \\
\hline ADFI, g & 391 & 429 & 438 & 446 & 364 & 19.89 & NS & NS & NS & NS \\
\hline GF & 0.42 & 0.50 & 0.57 & 0.53 & 0.58 & 0.03 & $*$ & NS & NS & NS \\
\hline \multicolumn{11}{|c|}{$30-42$ days } \\
\hline $\mathrm{ADG}, \mathrm{g}$ & 220 & 262 & 317 & 317 & 284 & 12.45 & NS & NS & NS & NS \\
\hline ADFI, g & 494 & 503 & 571 & 564 & 479 & 15.78 & NS & NS & NS & NS \\
\hline GF & 0.44 & 0.52 & 0.55 & 0.56 & 0.59 & 0.03 & $*$ & NS & NS & NS \\
\hline
\end{tabular}

$\mathrm{C} 1$ : NC vs other treatments; C2: 50\% vs 100\%; C3: 50\% IM vs 50\% OM; C4: $100 \%$ IM vs $100 \%$ OM. $* P<0.05$; NS: nonsignificant. 
in diet had higher ADG and higher G:F compared to pigs from control treatment. Assessing the total period (21 to 63 days of age), ADFI and ADG were not affected by treatments $(P>0.05)$. Nevertheless for $\mathrm{G}: \mathrm{F}$, piglets supplemented with trace minerals showed better values for this variable.

During lactation, the majority of trace minerals ingested by pigs corresponds to the milk, so at first week post-weaning they still have reserves of these elements which become depleted if there is no supply. In this sense, it is observed that the effect of non supplementation becomes more pronounced from the second week post-weaning, worsening the performance of piglets. The absence of trace mineral supplementation for piglets from 53 days old was observed by Mello et al. (2012), suggesting that the body reserves would be insufficient to meet the requirement for trace minerals in piglets from this age.

Although there was no difference in performance of pigs fed diets containing organic and inorganic sources, the results present the possibility of reducing the amount of some trace elements in up to $50 \%$ of what is required, obtaining the same performance of piglets, considering the performance of animals from 0 to 42 days of experimental period. Mello et al. (2012), comparing levels of supplementation of trace minerals in organic form, noted that the level of $25 \%$ of what is required promoted performance similar to animals fed diet containing the total requirement. Likewise, the possibility of reducing up to $30 \%$ of trace minerals requirement in diets for pigs was demonstrated by Burkett et al. (2005), when supplemented in organic form.

It was observed that animals fed diets with $50 \%$ of trace mineral supplementation in inorganic form presented higher diarrhea occurrence, followed by those of 50\% OM and 100\% IM treatments. Lower values for diarrhea occurrence were observed in animals fed $\mathrm{NC}$ and $100 \% \mathrm{OM}$ (Table IV). The lower diarrhea incidence in piglets fed diets without mineral supplement (NC) may be partly accounted for by the lower intestinal osmolarity. It has been well documented that piglet diarrhea may be associated with enteric pathogens proliferation and nutritional imbalance, such as an increase in intestinal osmolarity (Etheridge et al. 1984). The increase in intestinal osmolarity causes gut inflammation by the reduction of the enzymatic secretion and nutrients absorption.

Hematological PARAmeters

There were no treatment differences $(P>0.05)$ in the concentrations of leukocytes, eosinophils, segmented neutrophils, and lymphocytes. Significant difference was observed $(P<0.05)$ for the concentration of red blood cells, with a higher concentration of this blood component in animals of

TABLE IV

Effects of inorganic and organic trace mineral supplementation on diarrhea occurrence of weanling pigs.

\begin{tabular}{ccccccccc}
\hline & \multicolumn{9}{c}{ Treatment } & & & \\
\cline { 2 - 6 } Fecal score & Control & $\begin{array}{c}\mathbf{5 0 \%} \\
\text { ITMP }\end{array}$ & $\begin{array}{c}\mathbf{5 0 \%} \\
\text { OTMP }\end{array}$ & $\begin{array}{c}\mathbf{1 0 0 \%} \\
\text { ITMP }\end{array}$ & $\begin{array}{c}\mathbf{1 0 0 \%} \\
\text { OTMP }\end{array}$ & Total & SEM & \% \\
\hline Score 1 & 95 & 72 & 116 & 90 & 117 & 490 & 1.28 & 34.27 \\
Sscore 2 & 172 & 148 & 122 & 154 & 133 & 729 & 0.88 & 50.98 \\
Score 3 & 27 & 60 & 51 & 42 & 31 & 211 & 2.09 & 14.75 \\
Total & 294 & 280 & 289 & 286 & 281 & 1430 & 0.14 & 100.00 \\
\% Escore 3 & $9.18^{\mathrm{a}}$ & $21.4^{\mathrm{c}}$ & $17.6^{\mathrm{b}}$ & $14.6^{\mathrm{b}}$ & $11.0^{\mathrm{a}}$ & 14.8 & & - \\
\hline
\end{tabular}

Means followed by the same letter do not differ by Kruskal Wallys test $(P>0.05)$. 
$100 \%$ OM compared to $100 \%$ IM (Table V). Pigs fed 50\% ITMP had higher hemoglobin and hematocrit levels compared with those fed 50\% OTMP. Some trace elements, due to the functions they serve, may result in physiological modulating when the requirement is not met. Accordingly, the organic iron supplementation at full recommendation, results in higher number of red blood cells in comparison with inorganic supplementation of this mineral. However, the opposite effect was observed when it dropped to $50 \%$ of the recommended for trace mineral supplementation, with higher values for hemoglobin and hematocrit in animals supplemented with inorganic trace minerals.

The control pigs showed higher values of rod neutrophils $(P<0.05)$ than the other treatments. Depending on the cellular phenomena caused by an inflammatory process, it is observed that the greater presence of neutrophils corresponds to acute inflammation (Eckmann et al. 1993). Thus, the absence of supplemental trace minerals for piglets could result in immune response due to an inflammatory process.
Difference was observed $(P<0.05)$ for monocytes value, whereas animals fed diets having $50 \%$ of trace mineral recommendation, regardless of the supplementation form, showed higher percentages of this fraction compared to those fed diets with $100 \%$ of the recommendations. Accordingly, because the blood sample was performed at 50 days of age, in addition to the acute effect observed in the highest concentration of white cells, it was observed which is considered the early stage of the chronic inflammatory process, denoted by higher concentration of monocytes in animals receiving $50 \%$ of the trace mineral recommendation compared to those who received the minerals in its entirety. Excessive levels of trace mineral supplementation, above animal requirements, may promote antimicrobial action, such as zinc and copper, or metabolic action, in the case of selenium (Arthur et al. 2003). Therefore, the reduction of trace mineral supplementation at $50 \%$ of what is required resulted in poorer immune response against the challenge faced by the pig at nursery phase.

TABLE V

Effects of inorganic and organic trace mineral supplementation on hematological parameters of weanling pigs.

\begin{tabular}{|c|c|c|c|c|c|c|c|c|c|c|}
\hline \multirow[b]{2}{*}{ Item } & \multicolumn{5}{|c|}{ Treatment } & \multirow[b]{2}{*}{ SEM } & \multicolumn{4}{|c|}{ P-value } \\
\hline & Control & $\begin{array}{c}\mathbf{5 0 \%} \\
\text { ITMP }\end{array}$ & $\begin{array}{l}\mathbf{5 0 \%} \\
\text { TMP }\end{array}$ & $\begin{array}{l}100 \% \\
\text { ITMP }\end{array}$ & $\begin{array}{l}100 \% \\
\text { OTMP }\end{array}$ & & C1 & $\mathrm{C} 2$ & $\mathrm{C3}$ & $\mathrm{C} 4$ \\
\hline $\mathrm{He}, 103 \mu \mathrm{L}$ & 6.10 & 5.89 & 5.61 & 5.57 & 6.01 & 0.27 & NS & NS & NS & $*$ \\
\hline Hb, g.dL-1 & 12.04 & 12.18 & 11.12 & 11.37 & 11.80 & 0.26 & NS & NS & $*$ & NS \\
\hline $\mathrm{Ht}, \%$ & 38.00 & 38.23 & 36.04 & 36.09 & 38.19 & 0.20 & NS & NS & $*$ & NS \\
\hline Le, $\mu \mathrm{L}$ & 10.81 & 11.79 & 11.62 & 10.37 & 10.91 & 0.36 & NS & NS & NS & NS \\
\hline Eos, $\%$ & 1.35 & 1.43 & 1.32 & 1.36 & 1.28 & 0.28 & NS & NS & NS & NS \\
\hline $\mathrm{Nr}, \%$ & 1.72 & 1.50 & 1.47 & 1.30 & 1.36 & 0.73 & $*$ & NS & NS & NS \\
\hline Ns, $\%$ & 35.81 & 44.23 & 38.00 & 40.09 & 37.19 & 0.56 & NS & NS & NS & NS \\
\hline Linf, \% & 59.04 & 51.19 & 57.85 & 56.90 & 60.76 & 0.43 & NS & NS & NS & NS \\
\hline Mon, \% & 1.59 & 1.53 & 1.54 & 1.35 & 1.40 & 0.46 & NS & $*$ & NS & NS \\
\hline
\end{tabular}

He: erythrocytes, Hb: hemoglobin, Ht: hematocrit, Le: leukocytes; Eos: eosinophils; Nr: rod neutrophil; Ns: segmented neutrophils; Linf: lymphocytes; Mon: monocytes. C1: NC vs other treatments; C2: 50\% vs 100\%; C3: 50\% IM vs 50\% OM; C4: 100\% IM vs 100\% OM. Variables Eos, Nbt and Mon were transformed $(\mathrm{Y}+1)^{1 / 2} .{ }^{*} P<0.05$; NS: nonsignificant. 


\section{FECAL MinERAL EXCRETION}

No differences were observed $(P<0.05)$ for excreted $\mathrm{Ca}, \mathrm{K}, \mathrm{Mg}, \mathrm{Na}, \mathrm{S}, \mathrm{Fe}$ and $\mathrm{Zn}$ related to each mineral ingestion (Table VI). It was verified that animals of $50 \%$ OM excreted a higher amount of $\mathrm{P}$ that those from $50 \%$ IM treatment. A lower excretion of $\mathrm{Mg}$ for animals supplemented with $50 \%$ of what is required by inorganic source in comparison to those from 50\% OM treatment was also noted.

When comparing levels (50\% vs 100\%), regardless of source, it was observed that animals fed diets supplemented with $50 \%$ of the recommendations had lower amounts of $\mathrm{Cu}$ in the feces compared to those fed diets supplemented with $100 \%$ of what is required. Animals from $100 \% \mathrm{OM}$ treatment excreted lower amount of this mineral when compared to those from $100 \%$ IM treatment.

In relation to $\mathrm{Mn}$, higher excretion of this mineral was observed from animals of control treatment. Comparing the treatments supplemented with $50 \%$ of what is required, it was noted that animals fed diets supplemented with inorganic source excreted less amount of this mineral $(P<0.05)$ in comparison to animals fed diets supplemented with OM.
The major benefit of using organic trace minerals is due to the greater availability of these for the animals. As the amount of nutrients excreted is directly proportional to the concentration of these in the diet, with the addition of organic trace minerals in the feeding of pigs, it is possible to reduce the level of inclusion of trace minerals in the diet, achieving the same performance and still reducing the amount of minerals excreted, avoiding excessive supplementation. Therefore, relating the amount excreted with the amount of this mineral intake, it was found that the reduction of $50 \%$ of the trace mineral supplementation resulted in no decrease in bioavailability of minerals, except for copper. Creech et al. (2004) reported that trace elements in organic form at reduced levels in piglet diets did not decrease the performance, and there was even lower fecal excretion of $\mathrm{Cu}, \mathrm{Zn}$, and $\mathrm{Mn}$.

\section{MinERAL RETENTION IN METACARPALS AND LIVER}

There was no effect of treatments in $\mathrm{Ca}, \mathrm{P}, \mathrm{Mg}, \mathrm{S}$, and Fe levels in metacarpals of piglets, whereas the levels of $\mathrm{Cu}$ and $\mathrm{Mn}$ were lower when animals were fed diets supplemented with trace elements (Table VII).

TABLE VI

Effects of inorganic and organic trace mineral supplementation on fecal mineral excretion (\%).

\begin{tabular}{|c|c|c|c|c|c|c|c|c|c|c|}
\hline \multirow{2}{*}{ Item } & \multicolumn{5}{|c|}{ Treatment } & \multirow[t]{2}{*}{ SEM } & \multicolumn{4}{|c|}{ P-value } \\
\hline & Control & $50 \%$ ITMP & $50 \%$ ОТМР & $100 \%$ ITMP & $100 \%$ OTMР & & C1 & $\mathrm{C} 2$ & $\mathrm{C} 3$ & $\mathrm{C} 4$ \\
\hline $\mathrm{Ca}, \%$ & 19.43 & 10.71 & 17.66 & 17.65 & 16.03 & 7.08 & NS & NS & NS & NS \\
\hline $\mathrm{P}, \%$ & 55.48 & 25.12 & 51.27 & 40.91 & 46.93 & 17.20 & NS & NS & $*$ & NS \\
\hline $\mathrm{K}, \%$ & 13.42 & 11.25 & 12.97 & 14.45 & 12.13 & 5.57 & NS & NS & NS & NS \\
\hline $\mathrm{Mg}, \%$ & 27.55 & 16.17 & 28.69 & 29.45 & 27.31 & 12.12 & NS & NS & $*$ & NS \\
\hline $\mathrm{Na}, \%$ & 18.10 & 11.56 & 13.74 & 13.66 & 14.91 & 5.98 & NS & NS & NS & NS \\
\hline $\mathrm{S}, \%$ & 12.89 & 10.16 & 15.52 & 17.88 & 16.39 & 6.75 & NS & NS & NS & NS \\
\hline $\mathrm{Cu}, \%$ & 34.31 & 19.29 & 32.72 & 52.73 & 34.76 & 14.96 & NS & $*$ & NS & $*$ \\
\hline $\mathrm{Fe}, \%$ & 70.72 & 35.44 & 56.52 & 61.75 & 60.46 & 24.47 & NS & NS & NS & NS \\
\hline $\mathrm{Mn}, \%$ & 59.56 & 18.96 & 45.44 & 37.78 & 46.71 & 19.59 & $*$ & NS & $*$ & NS \\
\hline $\mathrm{Zn}, \%$ & 37.15 & 22.04 & 37.46 & 33.33 & 34.19 & 15.31 & NS & NS & NS & NS \\
\hline
\end{tabular}

$\mathrm{C} 1$ : NC vs other treatments; $\mathrm{C} 2: 50 \%$ vs $100 \%$; C3: 50\% IM vs 50\% OM; C4: $100 \%$ IM vs 100\% OM. *P<0.05; NS: nonsignificant. 
With respect to the amounts of supplementation (50\% vs 100\%), it was noted that the deposition of potassium was higher and $\mathrm{Cu}, \mathrm{Mn}$, and $\mathrm{Zn}$ were lower when $100 \%$ of trace mineral recommendation was met. It was further found that the amounts of $\mathrm{K}, \mathrm{Na}$, and $\mathrm{Mn}$ were higher when animals received treatment $50 \% \mathrm{OM}$ and the deposition of Mn was lower when the animals received $100 \%$ OM. Revy et al. (2002) reported that two sources (organic and inorganic) and two levels of $\mathrm{Zn}(20$ and $30 \mathrm{mg} / \mathrm{kg}$ ) did not affect the minerals retention in metacarpals. The same was shown by Wedekind et al. (1994) in metacarpals and coccigea vertebrae of pigs that received higher $\mathrm{Zn}$ supplementation in diet.
Studies comparing organic and inorganic sources of $\mathrm{Cu}$ showed an increased uptake and retention of $\mathrm{Cu}$ in pigs fed organic source (Coffey et al. 1994, Veum et al. 2004), which was not observed in the present study for $\mathrm{Fe}, \mathrm{Cu}$, and $\mathrm{Zn}$ content in bones.

For mineral concentrations in the liver of piglets there were no differences $(P>0.05)$ for $\mathrm{Ca}$, $\mathrm{K}$, and $\mathrm{Mg}$ (Table VII). For the $\mathrm{P}$ content in liver, a difference was observed when comparing sources of minerals using the $100 \%$ of trace mineral recommendation and animals fed the inorganic source of trace minerals had higher amount of this mineral compared to those fed the organic source.

TABLE VII

Effects of inorganic and organic trace mineral supplementation on mineral composition (dry matter basis) of metacarpals and liver of weanling pigs.

\begin{tabular}{|c|c|c|c|c|c|c|c|c|c|c|}
\hline \multirow{2}{*}{ Item } & \multicolumn{5}{|c|}{ Treatment } & \multirow{2}{*}{ SEM } & \multicolumn{4}{|c|}{ P-value } \\
\hline & Control & $50 \%$ ITMP & $50 \%$ ОТМР & $100 \%$ ITMP & $100 \%$ ОТМР & & $\mathrm{C} 1$ & $\mathrm{C2}$ & $\mathbf{C 3}$ & C4 \\
\hline \multicolumn{11}{|c|}{ Metacarpals } \\
\hline $\mathrm{Ca}, \mathrm{mg}$ & 228056 & 226139 & 215790 & 229787 & 221934 & 0.17 & NS & NS & NS & NS \\
\hline $\mathrm{P}, \mathrm{mg}$ & 99526 & 96137 & 96490 & 97952 & 95426 & 0.11 & NS & NS & NS & NS \\
\hline $\mathrm{K}, \mathrm{mg}$ & 1675.0 & 1789.1 & 2236.7 & 2282.7 & 2147.9 & 0.91 & $*$ & $*$ & $*$ & NS \\
\hline $\mathrm{Mg}, \mathrm{mg}$ & 3588.0 & 3500.0 & 3425.3 & 3634.4 & 3578.1 & 0.16 & NS & NS & NS & NS \\
\hline $\mathrm{Na}, \mathrm{mg}$ & 7756.6 & 7395.5 & 7893.4 & 7856.6 & 7839.2 & 0.18 & NS & NS & $*$ & NS \\
\hline $\mathrm{S}, \mathrm{mg}$ & 1073.1 & 1200.8 & 1176.6 & 1061.2 & 1043.1 & 0.44 & NS & NS & NS & NS \\
\hline $\mathrm{Cu}, \mathrm{mg}$ & 4180.1 & 3675.2 & 3819.3 & 3362.5 & 3550.8 & 0.55 & $*$ & $*$ & NS & NS \\
\hline $\mathrm{Fe}, \mathrm{mg}$ & 60.50 & 60.44 & 62.15 & 63.52 & 61.68 & 0.14 & NS & NS & NS & NS \\
\hline Mn, mg & 4.74 & 4.22 & 4.61 & 4.19 & 3.82 & 0.57 & $*$ & $*$ & $*$ & $*$ \\
\hline Zn, mg & 50.14 & 109.31 & 104.09 & 116.86 & 121.50 & 1.87 & $*$ & $*$ & NS & NS \\
\hline \multicolumn{11}{|c|}{ Liver } \\
\hline $\mathrm{Ca}, \mathrm{mg}$ & 238.5 & 246.1 & 250.4 & 232.4 & 261.5 & 0.31 & NS & NS & NS & NS \\
\hline $\mathrm{P}, \mathrm{mg}$ & 1291.0 & 1262.5 & 1278.1 & 1325.6 & 1264.1 & 0.13 & NS & NS & NS & $*$ \\
\hline $\mathrm{K}, \mathrm{mg}$ & 10577.6 & 10967.4 & 11218.9 & 11418.5 & 11543.9 & 0.23 & NS & NS & NS & NS \\
\hline $\mathrm{Mg}, \mathrm{mg}$ & 638.3 & 665.2 & 630.9 & 630.9 & 642.7 & 0.15 & NS & NS & NS & NS \\
\hline $\mathrm{Na}, \mathrm{mg}$ & 3719.7 & 3670.5 & 4268.1 & 4161.0 & 4240.7 & 0.49 & NS & NS & $*$ & NS \\
\hline $\mathrm{S}, \mathrm{mg}$ & 26.9 & 37.3 & 33.7 & 34.3 & 34.3 & 0.77 & $*$ & NS & NS & NS \\
\hline $\mathrm{Cu}, \mathrm{mg}$ & 37.6 & 42.8 & 39.8 & 34.0 & 37.3 & 0.57 & NS & $*$ & NS & NS \\
\hline $\mathrm{Fe}, \mathrm{mg}$ & 515.0 & 826.1 & 837.5 & 866.7 & 673.0 & 1.32 & $*$ & NS & NS & $*$ \\
\hline Mn, mg & 17.6 & 12.9 & 14.5 & 15.0 & 12.9 & 0.88 & $*$ & NS & NS & NS \\
\hline $\mathrm{Zn}, \mathrm{mg}$ & 87.8 & 156.1 & 136.4 & 134.5 & 165.0 & 1.45 & $*$ & NS & $*$ & * \\
\hline
\end{tabular}

C1: NC vs other treatments; C2: 50\% vs 100\%; C3: 50\% IM vs 50\% OM; C4: $100 \%$ IM vs 100\% OM. * $P<0.05$; NS: nonsignificant. 
For $\mathrm{Na}$, there was a significant difference when comparing the two sources at 50\% inclusion, with animals fed trace minerals in organic form having higher concentration of $\mathrm{Na}$ in liver. For $\mathrm{S}$ and $\mathrm{Mn}$, animals of $\mathrm{NC}$ showed lower concentrations of these minerals in the liver compared to the other treatments, which may be accounted for by the non-inclusion of trace mineral in the diet.

A difference was observed in $\mathrm{Cu}$ content in liver only when comparing levels of trace mineral in diets. Animals fed diets containing $50 \%$ of the recommendations had higher concentrations of $\mathrm{Cu}$ compared to those fed diets containing $100 \%$. With respect to $\mathrm{Fe}$, when comparing the $\mathrm{NC}$ to other treatments, the animals fed the diet without trace mineral supplementation had lower concentrations of this mineral in the liver. However, comparing the two sources of the supplementation under the level of $100 \%$, there was a greater retention of $\mathrm{Fe}$ in the liver of animals fed inorganic source.

Animals of NC treatment presented lower concentration of $\mathrm{Zn}$ in the liver. Comparing the sources of the trace mineral supplementation in $50 \%$ of what is required, animals fed the inorganic source showed higher levels of this mineral in the liver compared to those fed the organic source. Furthermore, when compared animals that received total supplementation of trace minerals in diet, those fed the organic source showed higher $\mathrm{Zn}$ concentration in the liver compared to those fed the inorganic source.

Evaluating sources of organic and inorganic trace mineral supplementation, Muniz et al. (2010) observed no change in the levels of Fe, Mn, Zn, and $\mathrm{Cu}$ in the liver of weaned piglets. Regarding the levels of supplementation, the results obtained on this study corroborate those found by Martin et al. (2011) who also observed that the concentration of trace elements in the liver increased with increasing levels of supplementation, indicating that among the organs of the digestive system, this would be primarily a storage organ for some minerals.

\section{CONCLUSION}

Trace mineral supplementation, regardless of source and level, improved growth performance of weanling pigs. The reduction at $50 \%$ of what is required for trace mineral reduces the excretion of some trace elements, and modulates some blood parameters, reflecting in changes of piglet immunological status.

\section{RESUMO}

Um estudo foi conduzido para avaliar os efeitos de microminerais inorgânicos e orgânicos na dieta em dois níveis de suplementação, sobre desempenho, ocorrência de diarreia, parâmetros hematológicos, excreção dos minerais nas fezes e retenção dos minerais nos metacarpos e fígado de leitões desmamados. Setenta leitões desmamados aos 21 dias de idade com peso médio inicial de 6,70 $\pm 0,38 \mathrm{~kg}$ foram distribuídos em cinco tratamentos: dieta controle (sem adição de premix micromineral); $50 \%$ ITMP (dieta controle contendo premix micromineral inorgânico atendendo a somente $50 \%$ da exigência em microminerais); 50\% OTMP (dieta controle contendo premix micromineral orgânico atendendo a somente $50 \%$ da exigência em microminerais); 100\% ITMP (dieta controle contendo premix micromineral inorgânico atendendo a $100 \%$ da exigência em microminerais); e $100 \%$ OTMP (dieta controle contendo premix micromineral orgânico atendendo a $100 \%$ da exigência em microminerais). Consumo de ração e o ganho diário de peso não foram afetados pelos tratamentos, entretanto, os leitões suplementados com microminerais apresentaram melhor eficiência alimentar. Não foram observadas diferenças para as quantidades de cálcio, fósforo, potássio, magnésio, sódio e enxofre excretados nas fezes por quilograma de alimento consumido. Os tratamentos não afetaram os teores de cálcio, fósforo, magnésio, enxofre e ferro nos metacarpos. A suplementação com microminerais, independente dos níveis e da fonte, melhorou o desempenho dos leitões.

Palavras-chave: fase de creche, desempenho, desmame, leitão. 


\section{REFERENCES}

Arthur JR, McKenzIE RC AND BeCKett GJ. 2003. Selenium in the immune system. J Nutr 133: 1457-1459.

BAKER DH. 1991. Bioavailability of minerals and vitamins. In: LEWIS AJ AND SOUTHERN LL (Eds), Swine Nutrition. Stoneham: Butterworth-Heinemann, p. 415-424.

Bataglia OC, Furlani AMC, TeIXeIRA JPF, Furlam PR AND GALlo JR. 1983. Métodos de análises químicas de plantas. Campinas: Instituto Agronômico, 49 p.

Burkett JL, Stalder KJ, Schwab CR, Powers W, BaAs T AND MABRY J. 2005. Growth comparison and fecal mineral excretion of inorganic and organic trace mineral supplementation in swine. Iowa State University Animal Industry Report, 8 p.

CASE CL AND CARLSON MP. 2002. Effect of feeding organic and inorganic sources of additional zinc on growth performance and zinc balance in nursery pigs. J Anim Sci 80: 1917-1924.

Coffey RD, CROMwEll GL AND MONEGUE HJ. 1994. Efficacy of a copper-lysine complex as a growth promotant for weanling pig. J Anim Sci 72: 2880-2886.

Creech BL, Spears JW, Flowers WL, Hill GM, Lloyd KE, Armstrong TA And Engle TE. 2004. Effect of dietary trace mineral concentration and source (inorganic vs. chelated) on performance, mineral status, and fecal mineral excretion in pigs from weaning through finishing. J Anim Sci 82: 2140-2147.

DELVES HT. 1982. Elemental analysis of body fluids and tissues by eletrothermal atomization and atomic absorption spectrometry. In: CANTLE JE (Ed), Atomic Absorption Spectrometry (Techniques and Instrumentation in Analytical Chemistry). New York: Elsevier, p. 377-380.

ECKMANN L, KAGNOFF MF AND FiERER J. 1993. Epithelial cells secrete the chemokine interleukin- 8 in response to bacterial entry. Infect Immun 61: 4569-4574.

ETHERIDGE RD, SEERLEY RW AND WYATT RD. 1984. The effects of diet on performance digestibility, blood composition and intestinal microflora of weaned pigs. J Anim Sci 58: 1396-1402.

KIRCHGESSNER M AND GRASSMANN E. 1970. The dynamics of copper absorption. In: MILLS CF (Ed), Trace Elements Metabolism in Animals. Edinburgh: Academic Press, p. 277-287.

MAHAN DC, CLINE TR AND RICHERT B. 1999. Effects of dietary levels of selenium enriched yeast and sodium selenite as sources fed to growing-finishing pigs on performance, tissue selenium, serum glutathione peroxidase activity, carcass characteristics, and loin quality. J Anim Sci 77: 2172-2179.
MARTIN RE, MAHAN DC, HiLl GM, LinK JE AND JOLLIFF JS. 2011. Effect of dietary organic microminerals on starter pig performance, tissue mineral concentrations, and liver and plasma enzyme activities. J Anim Sci 4: 1042-1055.

Mello G, Berto DA, Tierzo Vl, Augusto RMN, Silva AMR, TRINDADE NETO MA, VILLELA CCEJ AND GIRÃO LVC. 2012. Sources of organic trace minerals in diets for weaned piglets. Braz J Anim Sci 41: 1872-1877.

MELLOR D. 1964. Historical background and fundamental concepts "of chelation". In: DWYER F AND MELLOR D (Eds), Chelating agents and metal chelates. New York: Academic Press, p. 1-50.

Muniz MHB, Berto DA, Augusto RMn, Trindade Neto MA, WeChSLER FS, TIERZO VL AND HAUPTLI L. 2010. Organic and inorganic mineral sources for weanling piglets. Cienc Rural 40: 2163-2168.

REVY PS, JONDREVILLE C, DOURMAND JY, GuINOTTE F AND NYS Y. 2002. Bioavailability of two sources of zinc in weanling pigs. Anim Res 51: 315-326.

Rostagno HS, Teixeira LFA, Donzele JL, Gomes PC, OLIVEIRA RF, LOPES DC, FERREIRA AS AND BARRETO SLT. 2005. Brazilian Tables for Poultry and Swine: Composition of Feedstuffs and Nutritional Requirements, $2^{\text {nd }}$ ed., Viçosa: Editora UFV, 186 p.

Underwood EJ AND SutTle N. 1999. The Mineral Nutrition of Livestock, $3^{\text {rd }}$ ed., Wallingford: CAB Int, $624 \mathrm{p}$.

Vassalo M, Fialho ET, Oliveira AIG, Teixeira AS And BERTECHINI AG. 1997. Probióticos para leitões dos 10 aos $30 \mathrm{~kg}$ de peso vivo. Rev Bras Zootec 26: 131-138.

Veloso JAF, Medeiros SLS AND Costa ECA. 2000. Bone mineralization with four phosphorus sources in finishing pigs. Arq Bras Med Vet Zootec 52: 379-384.

VeUM TL, CARLSON MS, Wu CW, Bolliger DW AND ELLERSIECK MR. 2004. Copper proteinate in weanling pig diets for enhancing growth performance and reducing fecal copper excretion compared with copper sulfate. J Anim Sci 82: 1062-1070.

WedeKInd KJ, LeWIS AJ, Giesemann MA ANd MiLler PS. 1994. Bioavailability of zinc from inorganic and organic sources for pigs fed corn-soybean meal diets. J Anim Sci 72: 2681-2689. 
